\title{
Moderní teorie formování evropských států: čtyři teoretické tradice
}

\author{
JAN KALENDA*
}

Modern Theories of European State-Formation: Four Theoretical Traditions

\begin{abstract}
This paper deals with the question of theoretical classification of main research approaches to European state-formation. In this review author selects the most conceptual strands and examine research in state formation in last forty years. For this purpose author applies specific analytical model, which is based on three institutional dimensions (economic, politics and culture). Through this model he could draw main theoretical traditions to problem of state-formation, which are in this case: 1) Economical approach to state-formation. From this point of view states are products of economic dynamic. 2) Political approach, which focus on internal social regulation. 3) War approach, which concentrate on war and external social regulation. 4) Cultural approach, which sees state-formation such as product of cultural factors.
\end{abstract}

Keywords: state formation, institutional dimensions, Europe, historical development, theoretical traditions, research development

Úvod

Historická sociologie má hned několik nosných a zároveň dlouho se rozvíjejících témat. Mezi jedno z nich bezpochyby patří i formování evropských států, které mapuje tato přehledová stat. Hned v jejím úvodu bychom měli předeslat, že se budeme zabývat převážně teoriemi moderními, tedy těmi, jež z velké části pocházejí od badatelů druhé a třetí generace historických sociologů, ${ }^{1}$ autorů píšících o dlouhodobé sociální dynamice zhruba od přelomu 60. a 70. let 20. století. Čtenář v ní proto nenalezne ani diskusi pojetí státu a jeho vývoje u „otců zakladatelư “, ${ }^{2}$ ani v americké sociologii počátku minulého století. Přesto se pokusíme poukázat na určité klíčové ideové zdroje, řečeno s Randallem Collinsem [1994] na teoretické tradice, jež jako velmi dlouhý stín doprovázejí výzkum politických režimů v posledních třiceti až čtyřiceti letech.

Co je přesně proces formování evropských států? Pro většinu badatelů jde o proces dlouhodobých proměn klíčové politické instituce, která zabezpečuje regulaci sociálního života jak ve vztahu k vnějšímu, tak v relaci k vnitřnímu prostředí. Stát podle většiny autorů prošel celou sérií strukturálních proměn, modifikací, krystalizací a institucionálních inovací, které z původně extrémně diverzifikované struktury feudálního světa vytvořily moderní národní státy. Naše definice tohoto sociálního procesu je skutečně prozatímním vymezením, přičemž podrobnější odpověd’ na předloženou otázku by měl nabídnout právě text této studie.

\footnotetext{
* Jan Kalenda, Katedra sociologie a andragogiky, Filozofická fakulta, Univerzita Palackého, třída Svobody 26, 77200 Olomouc. E-mail: jankalenda@seznam.cz

$1 \quad \mathrm{~V}$ tomto bodě se přidržuji jednoho z nejlepších úvodů do historické sociologie od Dennise Smitha [1991] a jeho členění badatelských generací.

2 Je možné ji nalézt v publikaci dvojice francouzských sociologů Bertranda Badieho a Pierra Birnbauma [1983: kap. 1.].
} 
V samotné sociologické literatuře nalezneme hned několik pokusů o klasifikaci diskursu formování států. ${ }^{3}$ Podle našeho soudu však ani jeden $z$ nich skutečně nenabízí schéma, jež by rovnoměrně integrovalo veškeré badatelské přístupy a zároveň nestranilo jednomu z nich. Navíc je valná většina soudobých roztřídění badatelů a jejich teorií poněkud „statická“, tzn., že nijak neproblematizuje otázku historického vývoje, kumulace znalostí a konvergence samotných teorií. Z těchto dvou důvodu nebudu následovat žádnou z předcházejících analytických mřížek, ale použiji mřížku zcela odlišnou a souběžně s jejím použitím se pokusím i o chronologickou klasifikaci badatelů a ideových tradic.

Jako základ naší klasifikace jsme vybrali tři institucionální dimenze - ekonomickou, politickou a kulturní, které podle mnohých sociologư tvoří integrální prostředí společnosti, pomyslnou strukturu rámující veškerý sociální život. Jednotliví autoři, jež se věnují otázce vývoje evropských států, se od sebe liší právě důrazem, který kladou na jednu z těchto dimenzí. Někteří považují formování států za produkt působení ekonomických struktur, jiní zdůrazňují roli politické regulace a integrace, anebo v rozporu s tím úlohu makrosociálního konfliktu, zejména střetů mezi státy, jiní sociologové naopak směřují k preferenci kulturních veličin vstupujících do mechanismů formování států.

Samosebou, že žádný z badatelů není v tomto ohledu úplným dogmatikem; to znamená, že by ignoroval působení jiných institucionálních sfér, než té, kterou sám preferuje. Nicméně právě díky tomu, že je u některých badatelů orientace na určitou dimenzi mnohem výraznější, můžeme tímto způsobem sestavit klasifikační výkladové schéma.

Na základě jednoduchého schématu, jehož ideová východiska lze nalézt v díle Michaela Manna [1986], můžeme říci, že se od přelomu 60. a 70. let vyvinuly celkem čtyři klíčové teoretické přístupy ke studiu formování států: 1) Nejprve to byl ekonomizující přístup, který se objevil v 70. letech a převládal až do poloviny 80. let. 2) Souběžně s ekonomizujícím přístupem se rozvíjela politizující tradice analýz, která preferovala otázku interní sociální regulace společnosti. 3) V polovině 80. let navázala na oba předcházející

3 Asi úplně prvním pokusem je členění Barkheyové a Parikhové [1991: 526-531]. Obě vědkyně identifikovaly tři dílčí množiny autorů: první, spojující vznik států s vedením válek; druhou, považující státy za důsledek různorodých sociálních krizí, které mají samy překonat; třetí, dávající stát do spojitosti s kulturní dynamikou. Nicméně jejich výběr badatelů pod různé směry je značně selektivní.

S vlastním členěním přišel i Charles Tilly [1992: 5-11], který odlišuje autory podle podílu dvou kritických proměnných: původu státní struktury, ta může být vnitřní či vnější, a vztahu k ekonomické sféře, ten se může projevovat závislostí nebo nezávislostí formačních procesů na hospodářské dynamice. Na základě těchto kategorií Tilly diagnostikoval čtyři skupiny teorií: 1) světový systém [např. Wallerstein 1974], 2) analýzu druhu produkce [např. Anderson 1974a, 1974b], 3) státocentrickou analýzu [např. Olson 1982], 4) geopolitickou analýzu [např. Waltz 1979]. Na druhou stranu Tilly upozorňuje, že mnohé teorie, včetně té jeho, nelze ani do jednoho z přístupů zařadit.

Michael Mann [1993: 44-52; srovnej též Mann 1984] přispěl o rok později svou vlastní strukturací teorií; rozlišil celkově čtyři skupiny: třídní (marxistickou), pluralistickou (neoliberální), státocentrickou, k níž se s určitými výhradami sám hlásí, a „dílčí“, většinou induktivně sestavované teorie.

Čtvrtý zásadní pokus o klasifikaci badatelů spadajících do vědeckého pole formování států máme od britsko-italského sociologa Gianfranka Poggiho [2003: 253-259]. Ten identifikuje podobně jako předcházející autoři čtyři sady teorií: 1) autoři tematizující sjednocování a rozpad států (geopolitická analýza), 2) válečný přístup, preferující konflikt mezi státy jako rozhodující proměnnou, 3) interní řízení, které zdůrazňuje regulační funkce státu ve vztahu k občanské komunitě, 4) přístup zabývající se kontinuitou vládnoucích aktérů (marxismus a teorie elit). Kromě těchto statí jsou postřehnutelné náznaky o určité roztřídění soudobých bádání v některých studiích Philipa S. Gorskiho [2001: 851-853, 2005].

4 Srovnej např. [Collins 1986, 1999; Gellner 2001; Parsons 1954; Poggi 2006]. 
přístupy tzv. válečná teorie, které se podařilo integrovat velkou část poznatků obou předcházejících vědeckých tradic do svých vlastních analytických rámců. Přes určitou konvergenci ona sama upřela svou pozornost ke konceptualizaci externí sociální regulace. Tento směr převládal po celá 90. léta, a dokonce i dnes lze říci, že jde o stanovisko dominující. 4) Od začátku 90. let se jako kritika bádání „bojové školy“ postupně objevuje kulturalistický směr, jenž však nedosahuje rozsahu ani explanační síly předcházející teoretické formace.

Ještě než přejdeme $\mathrm{k}$ podrobnějšímu rozboru jednotlivých výzkumných tradic, je třeba uvést, že budeme věnovat větší pozornost badatelům, kteří se věnují mechanismům formování států z makrostrukturního (časového i prostorového rozsáhlejšího) hlediska, než těm, jež se zabývají dílčími tématy, volně souvisejícími s formováním státních režimů.

\section{Ekonomizující přístup: Formování evropských států jako produkt ekonomických transformací}

O stát, jeho vývoj a transformace se moderní sociologie dlouho nezajímala. Opomíjela totiž fakt, že společnost, hlavní předmět jejího zájmu, a stát nejsou stejné entity. Stát byl proto považován pouze za jakýsi epifenomen existence společnosti, uvnitř něhož se společnost vyskytovala. Po celá 50. a 60. léta upínala svou pozornost spíše k otázkám systémové teorie či mikroanalýz sociálního života, z nichž byl stát vytěsněn. Výjimku tvořila tradice marxistického myšlení, která se však primárně věnovala státu modernímu a jež jej poněkud zjednodušeně považovala za aparát dominance vládnoucí třídy. ${ }^{5} \mathrm{~S}$ postupným rozvojem a institucionalizací historické sociologie se však začala situace měnit.

Znovuobnovení zájmu o vývoj států na začátku 70. let je spojeno s návratem dvou navzájem provázaných témat klasické sociologie - rozsáhlých ekonomických transformací, jimiž se dříve zabýval Karel Marx, a vzniku kapitalismu, velkého tématu Maxe Webera. Na obě tyto myšlenkové tradice navázala ze všeho nejdříve dlouhotrvající marxistická debata o přechodu z feudalismu ke kapitalismu, již odstartovala kniha britského historika Maurice Dobba Studies in the Development of Capitalism [1946; srovnej též Dobb 1950], na jejíž klíčové teze pak o něco později ostře zaútočil americký politický ekonom Paul Sweezy [1950], aby se k nastalé debatě nakonec připojili též mnozí další autoři [Hill 1953; Hilton 1953]. Zatímco Dobb považoval za primární vůdčí síly sociální změny vlastnické vztahy a s nimi provázaný třídní konflikt bortící feudální okovy, Sweezy pro osvětlení celého procesu preferoval tržní relace, tzn. rozvoj městských center a mezinárodního obchodu, napomáhající nahlodat kořeny feudálního řádu. Se začátkem 70. let tato debata znovuožívá a tentokrát k ní mají co říci autoři, kteří za jednu z klíčových složek přechodu od feudalismu ke kapitalismu (a v podstatě i sociální změny) považují stát. Z něj se stává důležitý vysvětlující nástroj a centrum analýz. Protože je pro konceptualizaci ekonomické změny nutné postihnout i dlouhodobou změnu politické sféry - vývoj státního aparátu, se navíc objevuje jako důležitá otázka formování evropských států.

S novými argumenty do zmíněného sporu přichází nejdřive britský marxistický historik a sociolog Perry Anderson [1974a, 1974b] a po něm americký sociolog Immanuel Wallerstein [1974, 1980, 1989], celou diskusi pak částečně uzavírá a dokresluje Robert

$5 \quad$ K velmi přehlednému exkurzu do tohoto tématu srovnej [Vincent 1987: kap. 5.]. 
Brenner [1976, 1977]. Zatímco Wallersteina můžeme s určitou nadsázkou považovat za pokračovatele sweezyovského př́istupu, pak Brennera a Andersona lze spíše zařadit do linie myšlení Maurice Dobba, i když, jak upozorňuje Holton [1981], Andersonův přístup je v mnoha ohledech inovativní; nejde o nijak rigidní marxismus, jak jej můžeme např́iklad vidět v pojednání Dobba.

Teorie všech tří vědců mají společné to, že kromě marxistické perspektivy považují formování států za derivát mnohem šiřre pojatých hospodářských změn, uprostřed nichž působí státní aparáty jako nezbytná mocenskopolitická nadstavba ovlivňující dílčí projevy ekonomické dynamiky. Přestože oba badatelé počítají i s jinými nežli ekonomickými faktory, je to stále transformace ekonomické sféry, která udává prim.

Podle Andersona [1974a] vznikly různorodé formy raných evropských království jako mocenská nadstavba feudální společenské formace. Jejich specifická podoba pak byla, více než čímkoliv jiným, dána nerovnoměrnou syntézou římského institucionální dědictví a elementů germánských komunit. Během krize feudalismu se evropské monarchie transformovaly do podoby absolutistických států. Nicméně absolutismus byl podle autora nejenom prostorově diferencován na západní a východní podtyp, ale, a to je podle Andersona [1974b: 15-16, 18] klíčové, stále představoval politickou instituci feudální základny, která měla sloužit jako krunýř politickými změnami ohrožené šlechty. ${ }^{6}$

Pro Wallersteina [1974, 1979] souvisí změny různých forem států s pulzováním dynamiky světového kapitalistického systému, který vzniknul uvnitř hranic evropského kontinentu v „dlouhém 16. století“. Nejdříve se objevily silné feudální monarchie, které, pokud se nacházely v jádru systému, profitovaly z rozvíjející se mezinárodní dělby práce. Jestliže se však nacházely na periferii nově vzniknuvšího hospodářského systému, dostaly se posléze pod negativní kontinuální tlak ekonomických sil. Díky tomu v Evropě vznikl hierarchicky nerovný mezistátní systém. Později, v průběhu 17. století, když kapitalistickou ekonomiku zasáhla recese, se poměry mezi jednotlivými oblastmi konsolidovaly a zároveň se jako pokus o přizpůsobení vzniklým obtížím objevil nový typ státu - absolutistický režim. ${ }^{7}$ Průmyslová a demokratická revoluce, odehrávající se zhruba o století až století a půl později, proměnila absolutistické státy ve zcela novou politickou jednotku - moderní stát s mechanizovanou výrobou, jehož legitimita již nespočívala na panovníkovi, ale přímo na jeho lidu. K těmto posledně jmenovaným změnám však nedošlo ve všech státech systému, ale pouze v těch zapojených do jeho jádra. To v důsledku znamenalo otevření možností další geografické expanze kapitalistické ekonomiky a likvidaci možných konkurenčních systémů v Orientu.

Prvenství ekonomické sféry a její převažující vliv na utváření státních struktur nás vede $\mathrm{k}$ zařazení ještě dalšího významného autora do tohoto teoretického přistupu, mezi sociology velmi dobře známého historika mezinárodních vztahů Paula Kennedyho [1996]. Kennedy se ve svých východiscích neopírá o myšlenky marxismu, ale přesto vidí jako jednu z vůdčích sil, podle mnohých kritiků [Giddens, Mann, Wallerstein 1989;

6 Robert Brenner [1976, 1977] v zásadě souhlasí s většinou Andersonových závěrů; odlišuje se od něj však při interpretaci vývoje francouzského a anglického státu, kdy upozorňuje na odlišné dopady feudální krize v těchto dvou teritoriích.

7 Wallersteinovo pojetí formování států se liší od Andersonova právě při interpretaci absolutistického režimu. Zatímco pro Wallersteina je absolutistický stát již kapitalistickým, pro Andersona je stále feudálním panstvím. 
Reynolds 1989; Woodruff 1989] v jeho práci naprosto převažující, právě v hospodářské síle jednotlivých zemí. Autorovu teorii vývoje evropských politických struktur lze vykládat i tak, že jde o jisté rozpracování některých myšlenek Immanuela Wallersteina s významnějším zdůrazněním konkrétního popisu mezinárodních vztahů a role války při jejich utváření. ${ }^{8}$ Kennedyho studie jistým způsobem představuje přechod mezi ekonomizujícím přístupem k formování evropských států a jeho „válečným ekvivalentem“, určitou konvergenci typickou pro badatele píšící na přelomu 80. a 90. let. ${ }^{9}$

\section{Politizující př́istup: Formování států jako řešení otázky interní sociální regulace}

Odpovědi na otázky, jak je navozována vnitřní rovnováha společnosti a jak je dosahováno její integrace, potažmo regulace, stojí v základech úvah všech badatelů zařazených do politizujícího přístupu k formování států. Politizujícím je v tomto individuálním př́ípadě míněn institucionální vývoj politické sféry. Je to totiž právě vznik nových politických institucí, jež vdechují život rozmanitým druhům a poddruhům států v průběhu více než tisíce let evropské historie.

Pod tento směr zařazení autoři se od sebe v mnoha ohledech významně liší. Výzvu konceptualizace politické dynamiky přijal jak strukturální funkcionalista Talcott Parsons [1971a, 1971b], tak proti funkcionalismu se ostře vymezující britský sociolog Anthony Giddens [1981, 1985]. Přestože oba zmíněné autory dělí jejich teoretická orientace, ideové dědictví i mnohé jiné prvky, usilují, a s nimi též mnozí další vědci, o popis vývoje „ř́zení“ lidské společnosti.

Není to ale jen otázka sociální regulace, která stojí v ohnisku jejich zájmu. Existují nejméně další tři velká témata, více či méně úzce provázaná s vývojem sociální regulace. Prvním z nich je podle těchto badatelů hledání vysvětlení pro dlouhodobý nárůst centralizace státní moci a komplementární růst státní autonomie v oddělování státu od společnosti. Při úvahách o postupně se prohlubující mezeře mezi společností a státní organizací narazili sociologové na další důležité téma, duální působení státu na společnost. To je badateli uchopováno různě, někdy má přídech negativní konotace a používání termínů pacifikace, disciplinace či monitorizace, jindy na sebe bere háv nárůstu sociální reprezentace, vlády lidu, emergence občanských, politických a sociálních práv, jak o ní psal ekonom Thomas Humphrey Marshall. Třetím tématem na politickou sféru orientovaných vědců je otázka samotného rozšiřování státního aparátu a vznik specifických strategií řízení státu: racionálního zasahování do chodu společnosti a byrokratizace. Stát redukovaný na byrokratickou modalitu postupně pohlcuje další a další sociální funkce, přebírá nad nimi svou záštitu a profiluje se v instituci racionální správy lidských záležitostí.

Právě tyto čtyři průvodní jevy formování států - sociální regulace, monopolizace moci a růst státní autonomie, vztah státu a společnosti a budování racionálně byrokratické správy - rámují výkladové schéma badatelů zařazených do následujícího oddílu studie [srovnej též Barkey, Parikh 1991, Poggi 2003].

$8 \quad$ Pro konkrétní podíl vlivu Wallersteinových myšlenek na Kennedyho studii srovnej poznámkový aparát v práci Vzestupy a pády velmocí [Kennedy 1996: 654-656, 661-662].

9 Kennedyho studii se v mnoha ohledech blíží též monografie Mancura Olsona [1982], jež však upřednostňuje úlohu interních sociálních koalic, které dodatečně ovlivňují hospodářský a tím i mocenský potenciál jednotlivých států v mezinárodním měrítku. 
V čem se politizující přístup liší od jiného směru formování států - „válečného přístupu“? Především v důrazu na kauzalitu a jednotku analýzy. Politizující přístup upřednostňuje jako vysvětlující jednotku stát a zdůrazňuje především ty procesy, jež se odehrávají uvnitř státních hranic. To neznamená, že by autoři této teoretické tradice neproblematizovali vztahy k jiným státům a působení vnějších sil na vnitřní struktury. Nikdy však tyto prvky neproměňují v jediný plně preferovaný vysvětlující nástroj tak, jako je tomu v případě válečné tradice. To je také asi důvod, proč můžeme pod jeden analytický směr zařadit autory tolika různých odborných východisek.

Jiným neméně důležitým rozdílem je časové ukotvení badatelů obou směrů. „Válečný směr“ postupně krystalizuje od poloviny 80. let a své plné síly nabývá až v 90. letech, částečně díky poznatkové syntéze ekonomizujících a politizujících rozborů formování států. V oblasti institucionálního vývoje politické sféry se bádá převážně v 70. letech a v první polovině 80. let. Tvoří určitý teoretický předvoj později nastupujících autorů z řad válečného přístupu. Tento časový posun má jednu důležitou konsekvenci, a to, že v rámci politizujícího konceptu převažuje až do poloviny 80. let spíše „společenskocentrický“ obraz politického vývoje než obraz „státocentrický“ [viz Evans, Rueschemeyer, Skocpol 1985]. Ten se plně rozvinul až ve druhé polovině 80. let. U statí autorů, které budeme dále rozebírat, nás proto nepřekvapí, že jsou v nich státy analyzovány stále jen jako jeden z mnoha agregátů společností, jako jedna ze struktur zasazená do mnohorozměrných procesů sociální změny.

Poslední poznámkou, kterou bychom měli učinit na adresu vztahu mezi politizujícím a válečným přístupem, je jejich komplementarita. Vztahy mezi sociálními jednotkami uvnitř státních hranic samozřejmě ovlivňují relace mezi státy a stejně tomu je i naopak. Proto válečný přístup, analyzovaný ve třetím oddíle této studie, stále vnímáme jako teoretickou tradici, která upřednostňuje vysvětlení vývoje států z pohledu politických institucí, tentokráte však institucionalizovaných vztahů mezi státy a válkou. Vnitřní a vnější regulace jsou tudíž dvěma stranami jedné mince a k jejich oddělení se zde uchylujeme pouze z analytických a výkladových důvodů. Můžeme totiž souhlasně s Clausewitzem [2008: 36] prohlásit, že „válka je pouze pokračováním politiky jinými prostředky“, a stejně souhlasně můžeme použít Foucaultovy [2005: 31] parafráze Clausewitzova aforismu a napsat, že „politika je pouze pokračováním války jinými prostředky“. ${ }^{10}$

Prvním autorem, kterého bychom mohli zasadit pod politizující př́ístup (otázku interní sociální regulace) je Talcott Parsons [1971a, 1971b]. Ten sice ještě setrvává v široce sociocentrickém přístupu k vývoji politické dimenze, přece jenom však ukazuje, že stát je jedním z klíčových činitelů sociální regulace. Jeho koncept zařazuje vývoj státu do nesmírně široce pojatého evolučního procesu společností a jejich systémových atributů. Stát se podobně jako jiné sociální systémy formoval v důsledku evolučních oscilací diferenciačních a integračních mechanismů, v nichž sehrával primární roli politického regulátora societální komunity. Podle Parsonse [1971b] došlo v Evropě od 9. do 19. století celkem ke třem rozsáhlým cyklům sociální diferenciace a integrace, které vyprodukovaly tři odlišné formy států: feudální, absolutistický a moderní zastupitelský stát.

Dílu jiného sociologa Norberta Eliase, přestože vzniklo o několik desetiletí dříve, se dostalo zasloužené pozornosti teprve uprostřed 70. let. Elias v mnoha ohledech

10 Anebo, jak stálo na pruských dělech 18. století, válka je ultima ratio regis; naprosto legitimním nástrojem prosazování státních zájmů, jeho politiky. 
předběhl dobu a ve svém „civilizačním procesu“ [2006, 2007] předznamenal mnoho z budoucího výzkumu na poli formování států, částečně i směr vývoje válečné teorie. Přesto je Elias stále klasickým reprezentantem politizujícího přístupu. Jeho pohledu neuniká regulace ani interního, ani částečně externího (mezistátního) sociálního konfliktu. Dále pak nastoluje problém růstu a monopolizace státní moci i její následné privatizace. A to vše s ohledem na kontury mnohem širšího procesu civilizování obyvatel Západu, pro něž formování států vytváří nezbytné strukturální podmínky. ${ }^{11}$

Dalo by se říci, že oběma předešlými autory je ovlivněn britsko-italský sociolog Gianfranco Poggi [1978, 1990], který na jedné straně zdůrazňuje, že usiluje o postihnutí institucionálního vývoje politické regulace v kontextu sociální evoluce (dlouhodobých diferenciačně-integračních mechanismů), na druhé straně čerpá také z mnoha Eliasových postřehů o feudalismu či absolutistické instituci dvora. Právě kombinace obou těchto ideových přístupů, společně s některými paralelami k Weberově práci a práci jiného německého teoretika Carla Schmitta, mu umožnila vytvořit vcelku vyvážený ideálně typický popis principiálních fází evropské politické institucionalizace, proces zahrnující politiku uvnitř státu i politiku mezi státy. Podle Poggiho prošly evropské státy celkově čtyřmi klíčovými fázemi přestavby: nejdříve se jednalo o feudální státy, poté o stavovskou vládu (Ständestaat), absolutistickou vývojovou sekvenci a nakonec se transformovaly v moderní konstituční státy 19 . století.

Dalším z badatelů 70. let, který zdůrazňoval vývoj států v interakci s povahou sociální regulace, byl Joseph R. Strayer [1970, 1971]. Ústřední teze Strayerových monografií vychází ze zjištění, že administrativní struktury různorodých státních aparátů se vyvinuly podle logiky interní krize, do níž se různě časoprostorově lokalizované společnosti dostaly. Státy v případě takových krizí nejdříve rozvinuly své soudní, správní a fiskální struktury regulující život obyvatelstva a vzápětí ustanovily i náležité vojenské a diplomatické aparáty, umožňující upravovat vztahy k jiným neméně podobným územním celkům. Podle Strayera mohlo za velkou část raného vývoje států úsilí velkých pozemkových vlastníků o řízení agrární produkce, do které stát nastoupil jako prostředník. ${ }^{12}$

Pro jiného badatele, Anthonyho Giddense, již není stát součástí jiných vývojových procesů, ale je to on sám, kdo je umístěn pod „drobnohled“ sociologické analýzy. Giddens tematizuje zejména vztah mezi vývojem státu a růstem jeho moci nad společností. Klade si otázku, jakým způsobem se z něj stává středobod sociálního života, schopný ve své moderní verzi ovládat individuální osudy i toho nejposlednějšího občana dané země. Giddensovu práci můžeme, podobně jako tomu bylo v případě Paula Kennedyho, považovat za určitou formu konvergence s nastupujícím válečným přístupem, předznamenání

11 Norbert Elias již záhy rozpoznal, shodně jako německý historik Otto Hintze [1975], úlohu války pro činnosti spojené s utvářením státní organizace. Ale ještě jednou zdůrazněme, že pro něj válka není klíčovou vysvětlující proměnou. Je to samo sebou důležitá síla, síla, s níž je třeba počítat, nikoliv však vše vysvětlující fenomén. Rozhodně ne fenomén, jímž by bylo možné poodhalit povahu takového jevu, jakým je civilizační proces.

12 S podobnou argumentací přichází rovněž monografie dvojice francouzských sociologů Bertranda Badieho a Pierra Birnbauma [1983], kteří dávají vznik státu coby autonomní organizace do spojitosti s feudální krizí. Během ní začal stát poprvé vystupovat v roli rozhodčího mezi dominantními tř́ídami jednotlivých historických etap. Stala se z něj vítaná institucionální inovace, umožňující spojit sociální tlaky z různých stran a alespoň na čas je sjednotit pod jediný zájem. Ovšem ve svém vývoji se stát nepokoušel různorodé třídy jen usmiřovat a sbližovat, ale zároveň se je pokoušel zničit a rozšírit nad nimi svou vlastní moc. 
teoretického směřování na stát zaměřených analýz, jelikož role války, jak Giddens [1985: 2] poznamenává, do té doby opomíjeného fenoménu, se pro porozumění vývoji státních aparátů stává nezbytnou. Giddensova studie je pak zajímavá ještě z jednoho do̊vodu. Nahrazuje totiž dosavadní evoluční model neevoluční teorií diskontinuitního vývoje jednotlivých institucionálních sfér, které autor nazývá klastry.

Jedna z posledních monografií, která byla uveřejněna na téma vývoje evropských států, pochází od holandského historického sociologa Martina van Crevelda [1999] působícího na Harvardově univerzitě. Ten pojímá vývoj státu jako jeho dlouhodobý kontinuální vzestup, růst administrativní moci a autonomie. Právě expanze institucionální dominance statní mašinérie stojí v centru jeho analýz, v nichž kombinuje poznatky různých př́stupů i badatelů. Výsledkem van Creveldovy práce je vyvážený mnohorozměrný model, poukazující k multidimenzionalitě (vlivu celé množiny distinktivně odlišných příčin a složek) celého formačního procesu.

\section{Válečný přístup: Formování států jako řešení otázky externí sociální regulace}

Jak jsme již v úvodu této studie naznačili, válečný přístup se objevil v polovině 80 . let a plně pak expandoval o desetiletí později, a to takovým zpơsobem, až se v jeden okamžik zdálo, jak poznamenává Philip S. Gorski [2001], že se stane naprosto převládajícím typem analýz státu. Za svou neobyčejnou vysvětlující sílu vděčí hned několika věcem. Jednak jako první plně zakotvil v státocentrickém manifestu vyhlášeném Thedou Skocpol a jejími kolegy v knize Bringing the State Back In [Evans, Rueschemeyer, Skocpol 1985], díky čemuž plně využil možností, jež nabízela vlna nově zaměřeného bádání. To začalo preferovat konkrétní státy (státní společnosti) namísto vágně a neurčitě vymezených konceptů společností, tak typických pro strukturální funkcionalismus a modernizační teorie 50. let. Na straně válečného přístupu dále stála dvojí poznatková revoluce, jež se odehrála dílem v historiografii, kde se někteří z historiků vojenství začali orientovat směrem na sociální procesy namísto „prostého“ líčení bitev a změn ve vojenské technologii, dílem se odehrála v teorii mezinárodních vztahů, která prodělala od 50. let bouřlivý vývoj. ${ }^{13}$

Souběh těchto dvou linií umožnil vidět státy jako jednotky principiálně zasazené do mezinárodního systému a válku jako fenomén, který se státem souvisí tak úzce jako málokterý. Především historiografická data o vlivu války na stát (statistiky státních výdajů, růst počtu úřadů, úředníků a vojáků, proměna daňových soustav i zákonů) umožnila postavit celý směr na pevné empirické základy, které oba předcházející přístupy (ekonomizující a politizující) v některých ohledech postrádaly. Nicméně i ekonomizující a politizující přístupy sehrály svou důležitou úlohu, nebơ na válku zaměřenou teorii lze z části vykládat jako jejich teoretickou konvergenci zasazenou do nového výkladového rámce. ${ }^{14}$ Otázky ekonomických souvislostí států a vnitřní sociální regulace se sice dostaly na druhou kolej, což ale neznamená, že by byly zapomenuty. Naopak byly do analýz znovu integrovány, jen s odlišným akcentem.

Jaká je centrální myšlenka tohoto směru? Válka je ústřední a v jednom okamžiku rozhodující proměnnou ovlivňující vývoj států. Její působení vytváří razantní tlak

13 Srovnej např. [Gilpin 1981; Holsti 1991; Singer 1979].

14 Jisté sbližování směrem $\mathrm{k}$ válečnému přístupu lze zaznamenat již v práci badatele ekonomizujícího př́istupu Paula Kennedyho a v modelech sociologů Anthonyho Giddense a Martina van Crevelda, reprezentantů politizujícího př́stupu. 
na centralizaci a expanzi státního aparátu, jelikož jenom tak může stát „přežít“ v nelítostném mezinárodním systému vzájemně soupeřících zemí, které si jsou nepřátelské. Jeden z nejnaléhavějších a nejilustrativnějších popisů tohoto stavu nabízí Charles Tilly [1975a: 15]. Evropa kolem roku 1500 se podle něj skládala z téměř 500 různorodých státních a kvazistátních celků (vévodství, panství, svobodných měst, částečně centralizovaných království, biskupství, volných městských lig a teokracií). O čtyři sta let později (v roce 1900) napočítáme v oblasti mezi Atlantikem a Uralem a na druhou stranu mezi Středozemím a Skandinávií 25 států. Kde zmizelo zbývajících pět stovek politických jednotek a uskupení? Odpověd je prostá. Byly pohlceny jinými státy a zničeny ve válkách. Jak již bylo zmíněno v úvodní debatě o politizujícím přístupu, kauzalita sociální změny je v tomto případě primárně vnější. Externí tlak z velké části ovlivňuje interní struktury států. Tím pádem se v rámci tohoto směru dostává velkého prostoru i debatě ohledně relací mezi jednotlivými územními jednotkami a jejich vzájemné koexistenci. Nicméně také zde stát stále zůstává politickou institucí, a proto se autoři se stejnou péčí obracejí ke vztahu mezi sociálními aktéry uvnitř jeho hranic.

Tím, že je na státy pohlíženo jako na celky zasazené do rozměrnějšího multistátního systému, je samozřejmě zdůrazněna státní autonomie, o níž v sociologii patrně poprvé důkladně referovala Theda Skocpol [1979]. Dále díky tomu, že státy jsou považovány za odlišné jednotky, objevuje se otázka konceptualizace různých vývojových cest, které jednotlivé země nastoupily. Badatelé se snaží nalézt příčiny, jež mohou za to, že se z jedněch zemí staly konstituční režimy, zatímco z jiných byrokraticko-absolutistické země. Tyto makrosociální problémy jsou v případě válečného přístupu také z velké části vysvětlovány skrze rozdílné působení konfliktní dynamiky.

Válečný přístup, podobně jako i jiné společenskovědní směry, má historii mnohem delší, než tu, která je mapována od 80. let. Jeho kořeny sahají až do přelomu 19. a 20. století a jsou spojeny se jmény zejména německých sociologů a komparativních historiků Ludwiga Gumplowicze [1899, 1912], Franze Oppenheimera [1975], Jacqua Novicowa [1911] a Otto Hintzeho [1975]. ${ }^{15}$ Obzvláště Hintze je díky překladu svých esejů mezi anglosaskými sociology natolik znám, že je někdy válečný přístup nazýván „neo-hintzenyánskou školou“ [Gorski 2001, 2003]. ${ }^{16}$

Je to ale skutečně Ludwig Gumplowicz, kdo je intelektuálním otcem tohoto směru. Sám o teoriích státu vydal publikaci, v níž od sebe odlišil různorodé přístupy k vývoji státu, které panovaly v závěru 19. století: organický směr, socialistický směr, právnickou školu, reální politiku a jím preferovanou sociologickou analýzu [Gumplowicz 1912].

15 Nejsou to ale jen němečtí badatelé, kteří se na začátku 20. století intenzivně věnují tématu války a státu. Američan Thorstein B. Veblen [(1914) 1946] v jedné ze svých nepř́iliš známých studií upozorňuje na to, že éra raně moderního ekonomického progresu (italské manufakturní výroby) se v mnoha ohledech shoduje s obdobím formování severoitalských městských států. Tato koincidence podle něj nemůže být náhodná a podle všeho souvisí s potřebou vladařů získat peníze pro válečné kampaně. To v důsledku vedlo k podpoře a ochraně prvních kapitalistů, kteří pro zeměpány zároveň představovali zprostředkovatele zdrojů pro vedení války. Těsné spojenectví mezi kapitalismem a státem tak bylo v renesanční laboratoři italských městských států, jakési Evropě v malém, navázáno již záhy [Veblen 1946: 268-272].

16 Někdy se též používá termín „strukturální weberismus“ [Kiser 2006] nebo „neo-weberismus“ [Collins 1999; Sanderson 1988]. K dalším pokusům o vymezení válečného přístupu srovnej velmi dobrý přehledový článek Johna A. Lynna Clio in Arms: Role of Military in Shaping History [1991] anebo Poggiho stat' o soudobých přístupech ke studiu státu [Poggi 2003; srovnej též Ertman 1997: 10-16]. 
Tak o formování států kupříkladu napsal: „Určitý stát, určitá ústava, určité dynastie vznikají sice prostřednictvím lidské vůle, ale nikoliv skrze lidskou vůli, nýbrž jako nevypočtený výsledek mnoha vưlí křížících se, a o sobě pojato směřujících za něčím docela jiným [op. cit.: 15]“. Autor nám již před bezmála sto lety naznačuje, že proces formování států je produktem nezamýšlených důsledků lidského jednání. V tomto konkrétním případě vedení války, jež podle něj ovlivňuje společnost hned třemi způsoby: 1) Státy vznikají jako systém jednoty vítězů a poražených, v němž se vítězové stávají privilegovanou vládnoucí skupinou, zatímco poražení jsou zbaveni práv a vykořistováni. 2) Normativní systém a zákony jsou výslednicí vůle vítězů válečných střetů i způsobu kontroly a vykořistování podřízených skupin. 3) Vítězství ve válečných konfliktech se posléze promítá i do sociální stratifikace, v níž vítězové obsazují post vyšší a poražení nižší třídy [Gumplowicz 1899]. ${ }^{17}$ Teorie německého sociologa byla především vzhledem ke kontaminaci rasovou teorií zdiskreditována a zapomenuta, a tak výzkum, v němž nejdříve započal Gumplowicz, se ze sociologické teorie na nějaký čas vytratil, aby po několika desítkách let pokračoval tam, kde německý sociolog skončil. ${ }^{18}$

Válka byla sociology na dlouho zapomenuta, aby se s novým leskem vrátila v 80. letech. Za první předvoj válečného přístupu můžeme považovat Charlesem Tillym [1975] editovanou práci The Formation of National States in Western Europe, v níž se pokusil se svými kolegy poodhalit některé ze strukturálních rysů evropského politického vývoje. Z našeho úhlu pohledu je zvláště důležité to, že se zde opětovně objevila válka jako rozhodující proměnná při vzniku a vývoji států. ${ }^{19} \mathrm{~V} 80$. letech pronikly poznatky této práce i do studií jiných badatelư ${ }^{20}$ a následně se objevily též jako jádro argumentů jedno z nejoriginálnějších sociologů současnosti Michaela Manna [1986, 1988, 1993].

Mann, preferující sítové paradigma, se pokusil načrtnout vývoj lidské společnosti v termínech různě se kř́žíících a proplétajících mocenských sítí. A právě z feudálního propletence čtyř sítí moci (ideologické, ekonomické, vojenské a politické) vyrůstají raně moderní státy, které Mann nazývá organickými. Politická moc, která reprezentuje v Mannových úvahách stát, následovala v průběhu posledního tisíciletí dva důležité trendy. Objevovala se u ní stálá tendence k expanzi, růstu jejích infrastrukturních kapacit, tzn. infrastrukturní moci (tj. „vlády skrze společnost“), která vrcholí až v průběhu 20. století, a tendence k navyšování despotické moci (tj. „vlády nad společností“). Ta eskalovala nejdřive na začátku 19. století, v autoritativních režimech pak dokonce ještě později. Deset století evropských dějin dalo vzniknout celkově čtyřem chronologicky na sebe

17 U tohoto autora lze nalézt i přímou výzvu všem společenskocentrickým teoriím, jež nereflektují stát jako důležitý činitel sociálního vývoje a existence. Při kritice takovéhoto pojetí u Herberta Spencera píše: „Místo, aby vycházel z nejbližších hmatatelných skutečností, místo, aby se tázal, jak vznikla Anglie, jak vznikla Francie, jak vznikly ostatní evropské státy, a usuzoval z nejověřenějších údajů dějin, těká, zaujat svojí myšlenkou organismovou, v oboru ethnografie, zobrazuje nám primitivní skupiny přírodních národů, aby od nich přes práh provedl fantastické salto mortale a zející mezeru mezi oněmi primitivními skupinami a státem, zastřel frází, že skupina ze sebe utvořila regulující agens“ [Gumplowicz 1912: 75]. Autoři usilující o „návrat státu zpět do teorie“ nebudou o sedmdesát let později tvrdit nic jiného.

18 Jedny z mála odkazů k raným úvahám z oblasti sociologie války lze nalézt v [Sorokin 1928: 309-34; Trnka 1917: 9-34]. V současnosti patří mezi nejvýraznější promotéry tohoto pole sociologického výzkumu Michael Mann [srovnej zvláště 1988: kap. 4., 5.] a Martin Shaw [1984].

19 Srovnej hlavně [Ardant 1975, Finer 1975, Tilly 1975a, 1975b].

20 Srovnej zvláště [Giddens 1985; Kennedy (1987) 1996; McNeill 1982; Parker 1988]. 
navazujícím formám mocenských krystalizací: feudálnímu státu, institucionálně vyzrálému teritoriálně centralizovanému režimu vrcholného středověku, raně modernímu organickému státu, v němž se na základě rozdílné funkcionální krystalizace vyvinuly dva dílčí typy - konstituční a absolutistický režim, a nakonec od poloviny 18. století se v několika sekvencích vyvíjejícímu polymorfnímu státu. Ten se dále diferencoval konstituční i absolutistickou formou vlády a prohloubil jak symbiózu jednotlivých druhů moci, tak variaci funkcí státního aparátu. V pozadí všech těchto změn stála podle Manna, krom jiných méně důležitých prvků, válka. Ta vyvíjela nejnaléhavější tlak na expanzi státních struktur a inkorporaci zbylých druhů sociální moci.

Devadesátá léta byla na rozvoj válečného přístupu ještě bohatší a nejdřive přinesla práci Coercion, Capital and European States, AD 990-1992, v níž Charles Tilly [1992; srovnej též 1985a, 1985b] „vybrousil“ mnohé ze svých argumentů z předcházející editorské práce a vytvořil zcela nový model formování evropských států. Ty jsou v tomto př́padě produktem vzájemné interakce přinucení a kapitálu, jež panovníci využívají ke správě svých panství a k přežití ve vražedném mezistátním systému. A podobně jako v Mannově př́padě je to opět válka, která empiricky (a statisticky) vede k nejintenzivnějšímu působení na rozvoj státních organizačních kapacit. Tilly však své argumenty v jednom důležitém ohledu inovoval: začal rozlišovat způsob budování státních režimů v oblastech bohatých a naopak chudých na kapitál, jež podmiňují jak rezistenci obyvatelstva proti těmto procesům, tak individuální formu samotného státu. ${ }^{21}$

Ve stejnou dobu jako se objevila Tillyho monografie, vyšla celá řada dalších studií, které více či méně následovaly argumenty válečného př́stupu. Mezi nejzdařilejší patří zajisté analýzy Bruce Portera [1994], zdůvodňující mocenský vzestup západu skrze vojensko-technologickou expanzi, a Briana M. Downinga [1988, 1989, 1992], který se snažil zdůvodnit rozdíly ve formách evropských států poukazem k odlišnému působení vojenské revoluce v 16. a 17. století. ${ }^{22}$ Tam, kde k revoluci došlo dříve, vyvinuly se autoritativní státy, naopak tam, kde geopolitická dynamika působila později a méně naléhavě, vznikly konstituční režimy.

Patrně nejpokročilejší studií, která v rámci válečného přístupu v průběhu druhé poloviny 90. let vůbec vyšla, je práce Thomase Ertmana Birth of Leviathan [Ertman 1997]. Lze ji považovat za určité rozpracování myšlenek Charlese Tillyho i jiných autorů této školy a v důsledku též za určité meze možností na válku orientovaných analýz. Tak Ertman se v rozporu se svými předchůdci tolik nevěnuje válce samotné, ale usiluje v prvé řadě o vysvětlení původu různých druhů raně moderních politických režimů: byrokraticko-absolutistických, byrokraticko-konstitučních, patrimoniálně-absolutistických a patrimoniálně-konstitučních států. K tomuto cíli úspěšně využívá komparativní metodu, která mu umožňuje sledovat rozdílné formační trajektorie, na něž se od roku 500 n. 1 . vydaly jednotlivé evropské regiony. ${ }^{23}$

Posledním autorem, na něhož bychom při našem výčtu neměli rozhodně zapomenout, je americký sociolog Randall Collins [1986, 1999], který sice k válečnému přístupu

21 Jádro této myšlenky se pravděpodobně nachází již v díle Tillyho učitele Barringtona Moora jr. [1966].

22 K dalším studiím - více či méně se zabývajícím vývojem států s ohledem na vedení válek - srovnej [Barbera 1998; Booney 1995; Brewer 1989; Kaiser 1990; Modelski, Thompson 1988; Thompson 1988].

23 Thomas Ertman v mnohém navazuje také na dědictví pokusů o vytvoření konceptuální makrostrukturní mapy Evropy, na níž v 70. letech pracoval norský sociolog Stein Rokkan [1975]. 
nepřispěl vlastní teorií, ale zato syntetizoval mnoho z jejích poznatků a umístil je do širších souvislostí. V Collinsově podání je proces vývoje politicko-územních jednotek nazývaných jako státy pouze jednou polovinou dlouhodobé geopolitické dynamiky, v níž státní režimy čelí bud’ expanzi svých struktur, anebo rozpadu a potencionální revoluci. Collins tak upozorňuje na důležitý fakt, že při retrospektivním zkoumání formování evropských států se sociologové obvykle zabývají pouze těmi zeměmi, které dosáhly bran modernity, a nikoliv těmi, jež v dlouhodobém procesu zanikly [Collins 1999].

\section{Kulturalistický přístup: Formování států jako produkt působení kulturních institucí}

Od konce 90. let se ve výzkumu formování států čím dál tím více uplatňuje rovněž kulturalistická tradice. Na její adresu musíme hned v úvodu učinit dvě důležité poznámky, nebơ se poznatkové jádro této školy teprve profiluje a ona sama není podobně vyhraněným směrem jako ty předešlé. Z části vzniká kulturalistický směr jako kritika přehlížení kulturních jevů a procesů při vzniku států, proto se ostře vymezuje zejména vůči bádání „bojové“ tradice, kterou obviňuje z jednostranného militaristického materialismu. Zčásti byly prvky kulturalistického směru obsaženy již v mnoha existujících analýzách, nikdy však netvořily autonomní teoretickou větev. Toto tvrzení by platilo rovněž pro jiné směry, nebơ žádný z nich, ačkoliv jsou charakteristické primárním zaměřením na některou z institucionálních dimenzí či subdimenzí, úplně neignoruje úlohu těch zbylých. V rámci různých teoretických matic se tedy neobjevují prostá monokauzální vysvětlení, nicméně určité proměnné jsou v analýzách preferovány.

Jádrem kulturalistických argumentů je tvrzení, podle něhož stát vytváří cíle, sebedefinici (tj. identitu) i klasifikační a interpretační schémata, která mu pomáhají ovládat jeho členy. V konečném důsledku se státní organizace stává kulturním symbolem, s nímž se občané státu identifikují. Státní aparát pak prostřednictvím různých kulturních praktik mobilizuje jedince pro své cíle a zájmy, čímž úspěšně reguluje své vztahy k prostředí.

O kulturalistickém směru tak můžeme říci, že byl nejdříve inkorporován v rámci dosavadních výzkumných linií, např́klad Michael Mann vyhrazuje, i když by s tím asi kulturalisté nesouhlasili, relativně velký prostor diskusi ohledně role ideologické moci při formování států. Taktéž mnozí další autoři zohlednili vliv některých kulturních prvků, zvláště pak nacionalizace a různých forem sociální kontroly, které s existencí státu bezprostředně souvisejí. Skutečně ale až v 90. letech se objevují badatelé, kteří z působení kulturní sféry na stát činí rozhodující a nezbytnou složku.

Jistě bychom mohli uvést, že tomuto tématu (vztahu kultury a státu) se věnovalo mnoho badatelů již v minulosti, ale musíme mít na paměti vymezení našeho vlastního výzkumného rámce a nezaměňovat zde badatele zabývající se formováním národů (nacionalismem) či mechanismy makrosociální kontroly [např. Foucault 1999, 2000] s vědci, jež se věnují dlouhodobým procesům formování států.

Za určitou předzvěst směru kulturalistických studií lze považovat některé statě francouzského sociologa Pierra Bourdieu [1994, 1998: 69 n.] a práci dvojice britských badatelů Corrigana a Sayera The Great Arch: English State Formation as Cultural Revolution [1984].

Jedním z nejvýznamnějších představitelů nového kulturalistického př́istupu ke státu je bezesporu Philip S. Gorski [1993, 2003]. Ten ve své práci rehabilituje Weberovu tezi o protestantské etice, kterou navíc spojuje s mechanismem disciplinární revoluce. 
Podle Gorskiho disciplinární revoluce (nárůst sebekontroly sociálních aktérů) způsobená kalvínským hnutím významným způsobem ovlivnila podobu a sílu vznikajících raně moderních států; obvykle tam, kde proběhla a uspěla nejdříve, vznikly první konstituční režimy. Gorski je též klíčovým promotérem celého kulturalistického směru [srov. zvláště Gorski 2001, 2005].

Mezi studie, jež by mohly být do tohoto přístupu ještě volně zařazeny, můžeme zařadit i monografii Paula K. Monoda [1999], v níž se věnuje dávno rozpracovanému tématu francouzského historika Marca Blocha: vztahu mezi panovníkem jako posvátnou a profánní osobou; nebo knihu feministické badatelky Pavly Miller [1998]. Monod se na rozdíl od Blocha nevěnuje středověku, ale rané modernitě, v níž sleduje nastupující diskurs racionálně účelové správy, krok za krokem nahrazující diskurs nadpozemské síly vladařů. Analýzy Millerové, principiálně ovlivněné feminismem a foucaultovsko-eliasovskými tradicemi, se věnují transformacím patriarchální vlády na úrovni státních struktur, které ve svém důsledku ovlivňují i mikroúroveň sociálního života a šíření sebedisciplíny. Ta je podle autorky též z velké části ovlivněna počínáním státní mašinerie; podle ní však výhradně dopadá na vyšší a střední třídu. Na velkou syntézu typu Wallersteina, Eliase, Tillyho či Manna tato oblast výzkumu stále ještě čeká.

\section{Závěr}

Jak jsme mohli sledovat v předcházejících částech textu, čtyři moderní tradice studia formování evropských států (ekonomizující, politizující, válečná a kulturalistická) nejenom že na sebe různorodým způsobem navazovaly a vzájemně se ovlivňovaly, ale z pohledu analýzy institucionálního vývoje, jsou ve skutečnosti komplementárními př́stupy. Nelze totiž oddělovat souběžné působení tři klíčových institucionálních dimenzí (kulturní, ekonomické a politické), aniž bychom přitom riskovali, že se vydáme na cestu př́lišného redukcionismu. Právě postupné sjednocování těchto tří klíčových pohledů umožnilo vidět státy jako autonomní jednotky zasazené v rozsáhlých ekonomických strukturách, bojující o své místo na slunci v rámci geopolitického systému, a stejně tak regulující život vlastní populace vystavené vlivu působení kulturních elementů. Nevyřešenou otázkou však stále z části zůstává časová analýza těchto procesů, nebot politická, kulturní a ekonomická sféra následuje vlastní rytmus temporální dynamiky; z části není ani dořešena otázka prostorové analýzy formačních procesů, unikátní vývoj jednotlivých zeměpisných oblastí evropského kontinentu.

Domnívám se, že současné zkoumání dějin evropské sociálně-politické dynamiky již nečelí výzvě, kterou Charles Tilly [1992: 33] formuloval jako opatrné kormidlování analýz mezi teleologickou nutností a absolutní jedinečností všech procesů, které považují každou historii za jev sui generis. Ale že samo bádání zamířilo ke konvergenci a integraci poznatkové báze, nebở je cíleně zaměřeno na jeden výzkumný problém v tomto př́padě formování států. To je zvláště patrné jak z našeho přehledu vývoje jednotlivých badatelských přístupů, tak z tvrzení klíčového představitele kulturalistického směru Philipa S. Gorskiho [1993: 266-268], jenž považuje své vlastní analýzy spíše za kritické doplnění předcházejících autorů, než za začátek zcela autonomní výzkumné školy.

Čeká tedy budoucnost výzkumu formování evropských států úplné sjednocení teoretických př́istupů pod jediný „multidimenzionální“ směr? I když lze takové tendence u některých z posledních příspěvků z této oblasti zaznamenat [Barkey 2008; Buzan, 
Little 2000; Glete 2002] a i když můžeme nalézt u některých badatelů takto explicitně zformulovaný požadavek [Árnason 2009: 52-53; Hobden 1998], nezdá se, že by veškerý výzkum se ubíral právě tímto směrem. Problematika zkoumání vývoje států se na místo toho spíše drolí do dílčích rozborů, inspirovaných posledními společenskovědními přístupy: feminismem, post-strukturalismem či neoinstitucionalismem [srov. napr. Adams, Clemens, Orloff 2005: kap. č. 1.]. Konečnou odpověd’ na to, převáží-li v dané badatelské oblasti tendence k teoretickému sjednocení, anebo bude spíše rozložena do dílčích typů analýz, jež v posledních letech přináší vývoj společenských věd, nám dají až příští léta. 


\section{Literatura}

Adams, Julia - Clemens, Elisabeth, S. - Orloff, Shola. (eds.). [2005]. Remaking Modernity: Politics, History, and Sociology. Duke University Press.

Anderson, Perry. [1974a]. Passages from Antiquity to Feudalism. London: Verso.

Anderson, Perry. [1974b]. Lineages of the Absolutist State. London: Verso.

Ardant, Gabriel. [1975]. Financial Policy and Economic Infrastructure of Modern States and Nations. In. Tilly, Charles. The Formation of National States in Western Europe. Princeton: Princeton University Press.

Arnáson, Johann, P. [2009]. Civilizační analýza. Evropa a Asie opět na rozcestí. Praha: Filosofia.

Badie, Bertrand-Birnbaum, Pierre. [1983]. The Sociology of the State. Chicago: Chicago University Press.

Berbera, Henry. [1998]. Military Factor in Social Change. New Brunswick: Transaction.

Barkey, Karen-Parikh, Sunita. [1991]. Comparative Perspective on the State. Annual Review of Sociology 17 (1991), s. 523-549.

Berkey, Karen. [2008]. Empire of Difference: The Ottomans in Comparative Perspective. Cambridge: Cambridge University Press.

Bourdieu, Pierre a kol. [1994]. Rethinking the State: Genesis and Structure of the Bureaucratic field. In. Sociological Theory 12 (March 1994), No. 1, s. 1-18.

Bourdieu, Pierre. [1998]. Teorie jednání. Praha: Karolinum.

Brenner, Robert. [1976]. Agrarian Class Structure and Economic Development in pre-Industrial Europe, In. Past and Present 70 (Februar 1976), No. 1, s. 30-74.

Brenner, Robert. [1977]. The Origins of Capitalist Development: a Critique of Neo-Smithian Marxism. In. New Left Review 104 (July-August 1977), No. 4, s. 25-92.

Bonney, Richard. (ed.). [1995]. Economic Systems and State Finance. Oxford: Clarendon.

Brewer, John. [1989]. The Sinews of Power: War, Money and the English State, 1688-1783. New York and London: Knopf and Unwin Hyman.

Buzan, Barry; Little, Richard. [2000]. International System in World History. Remaking the Study of International Relations. Oxford: Oxford University Press.

Clausewitz, Carl von. [2008]. O válce. Praha: Academia.

Collins, Randall. [1994]. Four Sociological Traditions. New York: Oxford University Press.

Collins, Randall. [1986]. Weberian Sociological Theory. Cambridge: Cambridge University Press.

Collins, Randall. [1999]. Macrohistory. Essays in Sociology of the Long Run. Stanford, California: Stanford University Press.

Corrigan, Peter - Sayer, David. [1984]. The Great Arch: English State Formation as Cultural Revolution. Oxford: Oxford University Press.

Dobb, Maurice. [1946]. Studies in the Development of Capitalism. London: Routledge.

Dobb, Maurice. [1950]. Reply to "The Transition from Feudalism to Capitalism”. By Paul Sweezy. In. Science and Society (spring 1950), No. 1, s. 156-157.

Downing, Brian M. [1988]. Constitutionalism, Warfare, and Political Change in Early Modern Europe. In. Theory and Society 17 (January 1988), No. 1, s. 7-56.

Downing, Brian M. [1989]. Medieval Origins of Constitutional Government in the West. In. Theory and Society 18 (February 1989), No. 2, s. 213-247.

Downing, Brian M. [1992]. The Military Revolution and Political Change: Origins of Democracy and Autocracy in Early Modern Europe. Princeton: Princeton University Press.

Elias, Norbert. [2006]. O procesu civilizace. Díl I. Praha: Argo.

Elias, Norbert. [2007]. O procesu civilizace. Díl II. Praha: Argo.

Ertman, Thomas. [1997]. Birth of Leviathan: Building States and Regimes in Medieval and Early Modern Europe. Cambridge, Mass.: Harvard University Press.

Evans, Peter - Rueschemeyer, David - Skocpol, Theda. (eds.). [1985]. Bringing the State Back In. Cambridge: Cambridge University Press. 
Finer, Samuel E. [1975]. State-and Nation Buildig in Europe. The Role of Military. In. Tilly, Charles. (ed.). The Formation of National States in Western Europe. Princeton: Princeton University Press, s. 84-163.

Foucault, Michel. [1999]. Dějiny sexuality I. Praha: Herrmann a synové.

Foucault, Michel. [2000]. Dozerat’ a trestat. Zrod väzenia. Bratislava: Kaligram.

Foucault, Michel. [2005]. Je třeba bránit společnost. Praha: Filosofia, FÚ AV ČR.

Gellner, Ernest. [2001]. Pluh, meč a kniha. Struktura lidských dějin. Praha: CDK.

Giddens, A. [1981]. A Contemporary Critique of Historical Materialism. Vol. I. Power, Property, and the State. London: Macmillan.

Giddens, A. [1985]. Nation State and Violence. Second Volume of Contemporary Critique of Historical Materialism. Cambridge: Polity Press.

Giddens, Anthony - Mann, Michael - Wallerstein, Immanuel. [1989]. Comments on Paul Kennedy's The Rise and Fall of the Great Powers. In. The British Journal of Sociology 40 (Februry 1989), No. 2, s. 328-340.

Gilpin, Robert. [1981]. War nad Change in World Politics. New York: Cambridge University Press.

Glete, Jan. [2002]. War and State in Early Modern Period: Spain, the Dutch and Sweden as fiscal-military States, 1500-1660. London, New York: Routledge.

Gorski, Philip, S. [1993]. The Protestant Ethic Revisted: Disciplinary Revolution and State Formation in Holland and Prusia. In. American Journal of Sociology 99 (September 1993), No. 2, s. 265-316.

Gorski, Philip S. [2001]. Beyond Marx and Hintze? Third-Wave Theories of Early Modern State Formation. Comparative Studies in Society and History 43 (October 2001), No. 4, s. 851-861.

Gorski, Philip S. [2003]. Disciplinary Revolution: Calvinism, Confessionalism and the State Formation in Early Modern Europe, 1500-1750. Chicago: Chicago University Press.

Gorski, Philip S. [2005]. The Protestant Ethic and the Bureaucratic Revolution. Ascetic Protestantism and Administrative Rationalization in Early Modern Europe. In. Camic, Charles - Gorski, Philip S. - Trubek, David M. (eds.). Max Weber's Economy and Society. A Critical Companion. Stanford, California: Stanford University Press, s. 267-296.

Gumplowicz, Ludwig. [1899]. Outlines of Sociology. Philadelphia: American Academy of Political and Social Science.

Gumplowicz, Ludwig. [1912]. Dějiny novějších theorií o státu. Praha: Levné osvětové knihy, svazek 45.

Hill, Christopher. [1953]. The Transition from Feudalism to Capitalism. In. Science and Society (winter 1953), No. 1, s. 348-351.

Hilton, Rodney. [1953]. The Transition from Feudalism to Capitalism. In. Science and Society (winter 1953), No. 1, s. 340-348.

Hintze, Otto. [1975]. The Historical Essays of Otto Hintze. New York: Oxford University Press.

Holsti, Kalevi J. [1991]. Peace and War: Armed Conflicts and Internal Order 1648-1989. Cambridge: Cambridge University Press.

Hobden, Stephen [1998]. International Relations and Historical Sociology. Breaking down boundaries. London: Routledge.

Holton, Robert J. [1981]. Marxist Theories of Social Change and the Transition from Feudalism to Capitalism. In. Theory and Society 10 (November 1981), No. 6, s. 833-867.

Kaiser, David. [1990]. Politics and War. Conflict from Filip II. To Hitler. Cambridge, Mass.: Harvard University Press.

Kennedy, Paul. [(1987) 1996]. Vzestup a pád velmocí. Ekonomické proměny a vojenské konflikty $v$ letech 1500-2000. Praha: Nakladatelství Lidové noviny.

Kiser, David. [2006]. Mann's microfoundations: addresing neo-Weberian dilemas. In. Hall, John A. - Schroeder, Ralf (eds.). An Anatomy of Power. The Social Theory of Michael Mann. Cambridge: Cambridge University Press, s. 56-70.

Lynn, John A. [1991]. Clio in Arms: The Role of Military Variable in Shaping History. In. The Journal of Military History 55 (January 1991), No. 1, s. 83-95. 
Mann, Michael. [1984]. The Autonomous Power of the State: Its Origins, Mechanisms and Results. Archives européennes de sociologie 25 (1984), s. 185-213.

Mann, Michael. [1986]. The Sources of Social Power. Vol. I.: A History of Power from Beginning to $A D$ 1760. Cambridge: Cambridge University Press.

Mann, Michael. [1988]. States, War and Capitalism. Studies in Political Sociology. Oxford University Press.

Mann, Michael. [1993]. The Sources of Social Power. Vol. II.: The Rise of Classes and Nation-States, 1760-1914. Cambridge: Cambridge University Press.

McNeill, William H. [1982]. The Pursuit of Power: Technology, Armed Force, and Society since $A D$ 1000. Chicago: The University of Chicago Press.

Miller, Paula. [1998]. Transformation of Patriarchy in the West, 1500-1900. Indianopolis: Indiana University Press.

Modelski, George - Thompson, William. R. [1988]. Seapower in Global Politics, 1494-1993. Seattle: University of Washington Press.

Monod, Paul K. [1999]. The Power of Kings. Monarchy and Religion in Europe, 1585-1715. New Heven, London: Yale University Press.

Moore, Barrington jr. [1966]. Social Origins of Dictatorship and Democracy: Lord and Peasant in the Making of the Modern World. Boston: Beacon Press.

Novicow, Jacques. [1911]. War and its Alleged Benefits. New York: H. Holt and Company.

Olson, Mancur. [1982]. The Rise and Decline of the Nations. Economic Growth, and Social Rigidities. New Haven and London: Yale University Press.

Oppenheimer, Franz. [1975]. The State. New York: Free Life Editions.

Parker, Geoffrey. [1988]. The Military Revolution and the Rise of the West. Cambridge: Cambridge University Press.

Parsons, Talcott. [1954]. The Social System. New York: Free Press.

Parsons, Talcott. [1971a]. Společnosti: vývojové a srovnávací hodnocení. Praha: Nakladatelství Svoboda.

Parsons, Talcott. [1971b]. The System of Modern Societies. Englewod Cliffs, New Jersey: Prentice-Hall, Inc.

Poggi, Gianfranco. [1978]. The Development of the Modern State. A Sociological Introduction. Stanford, California: Stanford University Press.

Poggi, Gianfranco. [1990]. The State: Its Nature, Development, and Prospects. Stanford, California: Stanford University Press.

Poggi, Gianfranco. [2003]. The Formation of the Modern State and Institutionalization of Rule. In. Delanty, Gerard - Isin, Engin F. (eds.). Handbook of Historical Sociology. London: Sage Publications. s. 250-260.

Poggi, Gianfranco. [2006]. Political Power un-manned: a defence of Holity Trinity from Mann's military attack. In. Hall, John A.; Schroeder, Ralf (eds.). An Anatomy of Power. The Social Theory of Michael Mann. Cambridge: Cambridge University Press, s. 135-149.

Porter, Bruce D. [1994]. War and Rise of the State. Military Foundations of Modern Politics. New York: Free Press.

Reynolds, David. [1989]. The Rise and Fall of the Great Powers: Economic Change and Military Conflict from 1500 to 2000 by Paul Kennedy. In. The Historical Journal 32 (June 1989), No. 2, s. $475-487$.

Rokkan, Stein. [1975]. Dimensions of State Formation and Nation-Building: A Possible Paradigm for Research on Variations Within Europe. In. Tilly, Charles. (ed.). The Formation of National States in Western Europe. Princeton: Princeton University Press, s. 562-600.

Sanderson, Stephen K. [1988]. Neo-Weberian Revolution: A Theoretical Balance Sheet. In. Sociological Forum 3 (March 1988), s. 307-314.

Singer, David. (ed.). [1979]. Explaining War. Beverly Hills, California: Sage Publications.

Shaw, Martin. (ed.). [1984]. War, State, and Society. London: Macmillan.

Skocpol, Theda. [1979]. States and Social Revolution. Cambridge: Cambridge University Press.

Smith, Denis. [1991]. The Rise of Historical Sociology. Philadelphia: Temple University Press. 
Sorokin, Pitirim, A. [1928]. Contemporary Social Theories. New York, Evanston and London: Harper Torchbooks.

Strayer, Joseph R. [1970]. On the Medieval Origins of the Modern State. Princeton, New Jersey: Princeton University Press.

Strayer, Joseph R. [1971]. Medieval Statecraft and the Perspectives of History. Princeton, New Jersey: Princeton University Press.

Sweezy, Paul, M. [1950]. The Transition from Feudalism to Capitalism. In. Science and Society (spring 1950), No. 1, s. 134-156.

Thompson, William, R. [1988]. On Global War: Historical-Structural Approaches to World Politics. Columbia: Univerity of South California Press.

Tilly, Charles (ed.). [1975]. The Formation of National States in Western Europe. Princeton: Princeton University Press.

Tilly, Charles. [1975a]. Reflection on the History of European State-making. In. Tilly, Charles (ed.). The Formation of National States in Western Europe. Princeton: Princeton University Press. s. 3-83.

Tilly, Charles. [1975b]. Western State-Making anf Theories of Political Transforamtion. In. Tilly, Charles. (ed.). The Formation of National States in Western Europe. Princeton: Princeton University Press, s. 601-638.

Tilly, Charles. [1985a]. War Making and State Making as Organized Crime. In. Evans, Peter - Rueschemeyer, David - Skocpol, Theda. (eds.). Bringing the State Back In. Cambridge: Cambridge University Press, s. 169-186.

Tilly, Charles. [1985b]. The Big Structures, Large Processes, Huge Comparisions. New York: Russell Sage Foundation.

Tilly, Charles. [1992]. Coercion, Capital, and European States AD 990-1992. Oxford: Blackwell Publishing.

Trnka, Tomáš. [1917]. Filosofický problém války. Praha: Jan Laichtera.

Van Creveld, Martin. [1999]. The Rise and Decline of the State. Cambridge: Cambridge University Press.

Veblen, Thorstein B. [(1914) 1946]. The Instinct of Workmanship and the State of the Industrial Arts. New York: Viking Press.

Vincent, Andrew. [1987]. Theories of the State. Oxford: Basil Blackwell.

Wallerstein, Immanuel. [1974]. The Modern World System. I.: Capitalist Agriculture and the Origins of the European World Economy in the Sixteenth Century. New York, London: Academic Press.

Wallerstein, Immanuel. [1979]. The capitalist world-economy. Cambridge: Cambridge University Press.

Wallerstein, Immanuel. [1980]. The Modern World-System II.: Mercantilism and Consolidation of the European World Economy 1600-1750. New York: Academic Press.

Wallerstein, Immanuel. [1989]. The Modern World-System III.: The Second Era of Great Expansion of the Capitalist World Economy. New York: Academic Press.

Waltz, Kenneth N. [1979]. Theory o International Politics. New York: McGrew-Hill.

Woodruff, William. [1989]. The Rise and Fall of the Great Powers: Economic Change and Military Conflict from 1500 to 2000 by Paul Kennedy. In. The American Historical Review 94 (March 1989), No. 3, s. 719-721.

Jan Kalenda (1985) je interním doktorandem Katedry sociologie a andragogiky Univerzity Palackého v Olomouci. Po odborné stránce se věnuje problematice historické sociologie, zvláště pak aspektům evropského formováni států, sociologii války a revolucí, sociologii sportu a pornografie. 